\title{
Phytoplankton composition of the water and gastrointestinal tract of the mussel Diplodon enno (Ortmann, 1921) from São Francisco river (Bahia, Brazil)
}

\author{
T. Alves ${ }^{a, b}$, P. Lima ${ }^{b}$, G. M. S. Lima, , M. C. C. Cunha ${ }^{\text {, S. Ferreira }}{ }^{b, e}$, \\ B. Domingues ${ }^{b, e}$ and J. Machado ${ }^{b, e *}$ \\ anstituto Federal de Educação, Ciência e Tecnologia da Paraíba, Av. $1^{\circ}$ de Maio, 720, Jaguaribe, \\ CEP 58015-430, João Pessoa, PB, Brazil \\ bDepartamento de Produção Aquática, Instituto de Ciências Biomédicas de Abel Salazar - ICBAS, \\ Universidade do Porto, Rua de Jorge Viterbo Ferreira, 228, CEP 4050-313, Porto, Portugal \\ 'Universidade do Estado da Bahia - UNEB, Rua da Gangorra, 503, General Dutra, \\ CEP 48608-240, Paulo Afonso, BA, Brazil \\ 'Laboratório de Ecofisiologia de Microalgas e Microbiologia, Instituto de Tecnologia de Pernambuco - ITEP, \\ Av. Prof Luiz Freire, 700, Cidade Universitária, CEP 50740-540, Recife, PE, Brazil \\ ${ }^{\mathrm{e}}$ Centro Interdisciplinar de Investigação Marítima e Ambiental - CIIMAR, Universidade do Porto, \\ Rua dos Bragas, 289, CEP 4050-123, Porto, Portugal \\ *e-mail: jmachado@icbas.up.pt
}

Received: August 4, 2014 - Accepted: November 6, 2014 - Distributed: February 29, 2016

(With 3 figures)

\begin{abstract}
The knowledge on diet composition of the freshwater mussel Diplodon enno (Ortmann) would aid in its culture and propagation allowing, this way, the replacement of natural endangered populations in Brazil. Microalgae are the main food source for captive mussels and unionids have displayed an ability to sort algae based on the cellular characteristics prior to ingestion. The main objective of the present work is to analyze the phytoplankton composition of the water from and of the gastrointestinal contents of the mussel D. enno, as an initial step for development of a suitable rearing diet. Therefore, water samples and bivalve specimens were collected from S. Francisco River, city of Paulo Afonso, Bahia, Brazil. The microalgal composition found in water and stomach/gut content samples was very diverse being represented by the following divisions: Cyanophyta, Chlorophyta, Dinophyta and Heterokontophyta (Diatoms). Concerning the relative abundance of microalgae divisions, it is possible to state, for the water and gastrointestinal contents, that Cyanophyta represents $15 \%$ and $14 \%$, Chlorophyta $54 \%$ in both, Heterokontophyta $31 \%$ and $27 \%$ and Dinophyta $0 \%$ and 5\%, respectively. According to the Brazilian CETESB criteria for phytoplankton species classification, $50 \%$ of Cyanophyta and $15 \%$ of Chlorophyta species observed in the water samples were classified as "very frequent", as were $68 \%$ of Heterokontophyta and $33 \%$ of Chlorophyta species in the gut/stomach tract samples. Focusing at a species level, although in the water only Coelastrum sp. and Chroococcus sp. were observed in $100 \%$ and $75 \%$ of the samples, respectively, in the gastrointestinal tract the species Staurastrum sp., Aulacoseira sp., Scenedesmus sp. and Fragilaria crotonensis occurred in $80 \%$ to $100 \%$ of the samples. The present results showed that $D$. enno feeds not only on small chlorophytes microalgae, due to their convenient size that facilitates higher feeding rates, but also on large size diatoms, due to a possible nutritional advantage for the bivalves. Thus, a diet composed by large diatoms and small chlorophytes microalgae may be considered as the most reasonable for the maintenance of $D$. enno populations.
\end{abstract}

Keywords: phytoplankton, gastrointestinal tract, Diplodon enno, São Francisco River.

\section{Composição fitoplanctônica da água e do trato gastrointestinal do molusco Diplodon enno (Ortmann) do rio São Francisco (BA - Brasil)}

\section{Resumo}

O conhecimento da composição da dieta do molusco de água doce Diplodon enno é de extrema importância para a sua cultura e propagação, permitindo desta forma a recuperação de populações em perigo de extinção no Brasil. As microalgas são a principal fonte de alimento para moluscos filtradores e os uniónidos sendo selecionadas por estes com base nas suas características celulares. O principal objectivo deste trabalho é analisar a composição fitoplanctônica da água e do conteúdo gastrointestinal do molusco $D$. enno, de forma a desenvolver uma dieta apropriada ao seu cultivo. Para isso, amostras de água e espécimes de bivalves foram recolhidos do rio São Francisco, cidade de Paulo 
Afonso, Bahia, Brasil. A composição de microalgas encontrada na água e no conteúdo do estômago/intestino foi muito diversa, sendo representada pelas seguintes divisões: Cyanophyta, Chlorophyta, Dinophyta e Heterokontophyta (diatomáceas). Atendendo à abundância relativa de cada divisão de microalgas, podemos afirmar que na água e no trato gastrointestinal Cyanophyta representa $15 \%$ e $14 \%$, Chlorophyta $54 \%$ em ambos, Heterokontophyta $31 \%$ e $27 \%$ e Dinophyta $0 \%$ and $5 \%$, respectivamente. De acordo com o critério CETESB de classificação de espécies de fitoplâncton, $50 \%$ das espécies de Cyanophyta e 15\% das de Chlorophyta observadas nas amostras de água foram classificadas como "muito frequentes", tal como aconteceu para 68\% das espécies de Heterokontophyta e 33\% das de Chlorophyta nas amostras do conteúdo do trato gastrointestinal. Realçando as espécies presentes, apesar de apenas Coelastrum sp. e Chroococcus sp. terem sido observadas em 100\% e 75\% das amostras de água, respectivamente, nas amostras de trato gastrointestinal Staurastrum sp., Aulacoseira sp., Scenedesmus sp. e Fragilaria crotonensis foram identificadas em entre $80 \%$ e $100 \%$ das amostras. Os resultados deste estudo mostram que D. enno se alimenta não apenas de pequenas microalgas clorófitas, devido ao seu pequeno tamanho que possibilita maiores taxas de filtração, como também de diatomáceas maiores, devido a uma possível vantagem nutricional para os bivalves. Assim sendo, uma dieta composta por diatomáceas e pequenas clorófitas poderá ser considerada a mais indicada para a manutenção de populações de $D$. enno.

Palavras-chave: fitoplâncton, trato gastrointestinal, Diplodon enno, rio São Francisco.

\section{Introduction}

Freshwater mussels play important roles in limnological environments seen as they are a link in the food chain and help to maintain water quality (Bogan, 2008; Soares-Gomes and Pires-Vanin, 2005; Vaughn et al., 2008, Vaughn, 2010). Several studies report that freshwater bivalves are excellent freshwater biomonitors of the ecosystem status, in particular as accumulators of metals and trace elements (Elder and Collins, 1991; Ravera et al. 2003; Rodrigues et al. 2012) and being exposed to suspended solids and turbulence (Aldridge et al. 1987). Freshwater bivalves can also represent a great conservational tool because of their high longevity and particular sensitivity to water quality changes (Heller, 1990; Elder and Collins, 1991).

Currently, the species of Unionacea, or freshwater mussels, are among the most threatened groups throughout the world (Lydeard et al., 2004). According to Bogan (1993), although it has only recently begun to be recognized, the extinction of freshwater bivalves is happening since, at least, 1900. Bogan (1993) also stated that if all the endangered mussels disappear in the next 100 years, 54\% of the 297 living species of freshwater fauna present in North America will become extinct. Threats to the long-term survival of mussels include: degradation of mussel habitat (sediment loading, erosion, pollutants from improper agricultural, forestry, and mining practices); channelization, dredging and bridge construction; traffic (large vessels or domestic animal crossings); dams or other barriers to fish migration; over-harvest and illegal collecting (since many species of the Superfamily Unionacea are potential producers of pearls and buttons) and competition from non-native invasive species such as the zebra mussel (Dreissena polymorpha), the Asian clam (Corbicula fluminea), and in the particular case of Brazil species such as Limnoperna fortunei and Corbicula fluminalis (Avelar et al., 2014; Dudgeon and Morton, 1984; Gazulha et al., 2012; Panha, 1992; Uthaiwan et al., 2001, 2002; Pereira et al., 2012).

Machado et al. (2005) reported in the Brazilian red list of threatened species, that there are several endangered species from the Unionacea Superfamily in the Bahia area, such as, Diplodon rotundus, Anodontites soleniformes and Anodontites trapesialis proving the impact of human action on the freshwater bivalves in this region. Studies with Unionacea populations in São Francisco river are scarce and are essentially based on the population distribution (Lima, 2010).

To deepen the knowledge on the culture and propagation of Unionacea species is the main solution for the maintenance of their natural populations (Gatenby et al. 1997). Dietary studies are uncommon and the nutritional requirements for captive unionids, specifically juveniles, remain undetermined. The species from this superfamily are essentially filter feeders, feeding mainly of microalgae, protozoans, other planktonic microorganisms and organic debris (Kotpal, 1997).

Therefore, the objective of the present work is to analyze qualitatively the phytoplankton taxa composition in the stomach contents of the endangered mussel $D$. enno and also in the water they live. This represents an initial step towards the development of a suitable diet in order to aid the rearing of this species for reintroduction purposes.

\section{Material and Methods}

Ten specimens of juveniles of Diplodon enno (Family Hyriidae, Superfamily Unionacea) were collected on the $1^{\text {st }}$ of April of 2007, at the water channel that connects São Francisco river reservoirs of Moxotó and Paulo Afonso (-9.38971 latitude and -38.238574 longitude), belonging to CHESF (São Francisco Hydroelectric Company), City of Paulo Afonso, Bahia, Brazil (see Figure 1). At the time of the collection the river was $300 \mathrm{~m}$ wide, $15 \mathrm{~m}$ maximum deep and had a flow of $1.3 \mathrm{~m}^{3} \mathrm{~s}^{-1}$.

\subsection{Determination of physico-chemical parameters of the water}

The water samples for physico-chemical parameter were collected simultaneously with the juveniles of $D$. enno (see Figure 1 - pin), at each of the four sampling sites 
( $1 \mathrm{~m}$ distance between each - W1 to W4). The average value from bottom to surface was registered, within a water column with 3 meters in depth. The values for $\mathrm{pH}$, dissolved oxygen and temperature were determined using a U-22XD water quality analyser (Global Waters Instrumentations, U.S.A.), alkalinity, and hardness were determined with an Environmental Testing Bench Photometer C206 (HANNA, Brazil) and transparency was determined using a Secchi disc.

\subsection{Phytoplankton collection from the water}

Collection of phytoplankton samples for analyses followed the procedures described by Kovitvadhi et al. (2002, 2006). Water samples were collected from four different sampling points $1 \mathrm{~m}$ appart from each other. The samples were collected by dragging a plankton net ( $40 \mu \mathrm{m}$ mesh, $30 \mathrm{~cm}$ diameter) through the $3 \mathrm{~m}$ deep water column (from bottom to surface). After collection, samples were transferred to four plastic containers $(300 \mathrm{ml})$ and fixed with formaldehyde $4 \%$, being later analyzed in the laboratory at the Bahia State University (UNEB).

\subsection{Phytoplankton extraction from the stomach/gut content}

Mussels were collected near the margins, at depth of $3 \mathrm{~m}$, through diving. They were easily identified as they were just slightly buried in the sand or sometimes observed between rocks. Mussels were immediately placed in a thermal box containing ice, in order to be anesthetized and then taken to the laboratory where their gastrointestinal content was removed. Ten mussels ranging from 2 to $4 \mathrm{~cm}$ length were surgically opened in order to separate the stomach and the intestine from the remaining soft parts. Stomach and the region of the intestine that extends to the heart were carefully separated from the digestive gland. Then, each

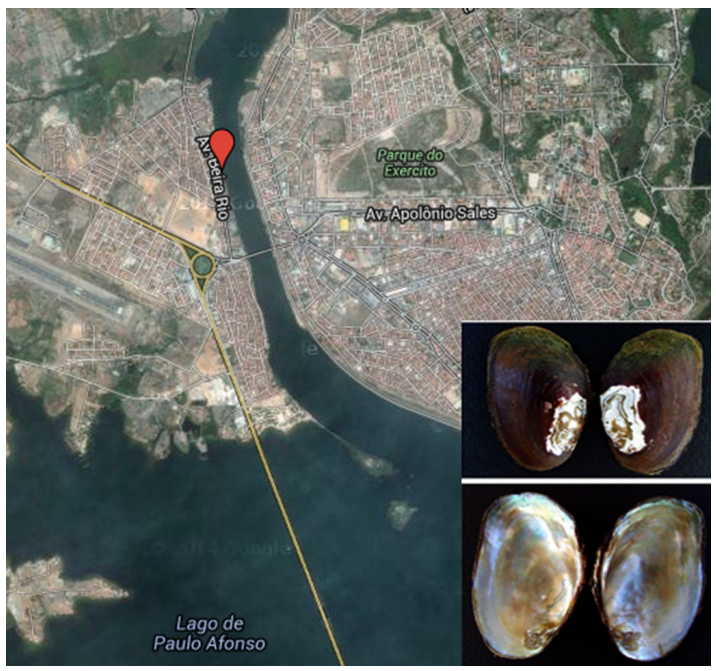

Figure 1. Map highlighting the channel that links Moxotó and Paulo Afonso reservoirs, next to Paulo Afonso city, with the sampling region marked with a pin. In the bottom right of the map a picture of the outside and inside shell views from two collected specimens of Diplodon enno. of these organs was tied on one end and its contents were squeezed in a test tube with water. The gastrointestinal content of each animal was fixed with formaldehyde (4\%) and then shaken to suspend the content.

\subsection{Water and stomach/gut phytoplankton analysis}

The samples of phytoplankton collected from the water and the gastrointestinal tract of ten bivalves were analysed qualitatively using Palmer Maloney Chambers, counting ten chambers per sampling point. From each test tube, three aliquots of $1 \mathrm{ml}$ were taken and prepared to be observed under a light microscope (Olympus BX41) coupled with a digital camera (Olympus DP70) (400x). The microalgae were identified according to the works of Branco (1978), Bourrelly (1966, 1968) and Lee (1999).

\subsection{Phytoplankton frequency index determination}

After the analyses, the frequency, indicating how many times one taxon is present in the set of samples index, was determined. The frequency index values were calculated according to the methodology determined by the state of São Paulo's Public Environmental and Sanitary Institution (CETESB, 1978). The formula: $F_{0}=$ Ta.100/TA was used, where Ta is the number of samples where the taxon occurred and TA is the total number of samples. The results were presented as percentages, using the following criterion: $>70 \%=$ very frequent $(\mathrm{VF}) ; 70 \% 40 \%=$ frequent $(\mathrm{F})$; $40 \% 10 \%=$ infrequent $(\mathrm{IF}) ;<10 \%=$ sporadically $(\mathrm{S})$. The case of non occurrence was added to the classification applying for this the term absent (A).

\section{Results}

The water from the river channel was at an average temperature of $26.25^{\circ} \mathrm{C}( \pm 0.2)$ and had an average $\mathrm{pH}$ of 7.7 ( \pm 0.2$)$. The mean values registered for dissolved oxygen and alkalinity were $7.5 \mathrm{mg} . \mathrm{l}^{-1}( \pm 0.8)$ and $50 \mathrm{mg} \cdot \mathrm{l}^{-1}$ $( \pm 1.2)$, respectively (as shown in Table 1 )

The physical parameters observed in the collected water seem to be within the expected values for São Francisco river. Furthermore, four phytoplankton phyla (Cyanophyta, Chlorophyta, Heterokontophyta and Dinophyta) where identified in the gastroinstestinal tract, whereas only three phyla (without Dinophyta) were identified in the water samples.

Table 1. Mean water physical and chemical parameters from the four water samples (1 $\mathrm{m}$ distance between each) registered in the stretch between Moxotó reservoir and Paulo Afonso reservoir at the time of sampling $(\mathrm{SD}=$ standard deviation).

\begin{tabular}{lr}
\hline & Mean \pm SD \\
\hline Temperature $\left({ }^{\circ} \mathrm{C}\right)$ & $26.25 \pm 0.2$ \\
Dissolved Oxygen (mg. 1-1) & $7.5 \pm 0.8$ \\
Alkalinity (mg. 1-1) & $50.0 \pm 1.2$ \\
pH & $7.7 \pm 0.2$ \\
Transparency (m) & $1.8 \pm 0.2$ \\
\hline
\end{tabular}


The results obtained for phytoplankton composition in the water show the importance of Chlorophyta, representing the largest contribution relatively to the number of taxa (54\%), the families Hydrodictyaceae and Desmidiaceae stand out with 3 and 4 taxa, respectively. Specimens from the families Heterokontophyta and Cyanophyta were also found in the analysed water samples, even though to a lesser extent $31 \%$ and $15 \%$ respectively (see Figure 2), no species of Dinophyta were found.

In the gastrointestinal content, as found in the water samples, Chlorophyta was predominant, representing 54\% of the total number of taxa. The divisions Heterokontophyta and Cyanophyta were also found in the samples, representing $27 \%$ and $14 \%$ respectively, Dinophyta had a smaller contribution to the gastrointestinal content representing only $5 \%$ of the total number of taxa (see Figure 3 ).

In the frequency index calculation for the water samples $50 \%$ of Cyanophyta species were classified as very frequent (VF) whereas and the remaining 50\% were classified only as frequent (F). $50 \%$ of the species from the division Heterokontophyta were classified as frequent (F) and the other half as infrequent (IF). Differently, the Chlorophyta division showed $15 \%$ of very frequent (VF), $57 \%$ of frequent (F) species and $28 \%$ of infrequent (IF) species (as shown in Table 2).

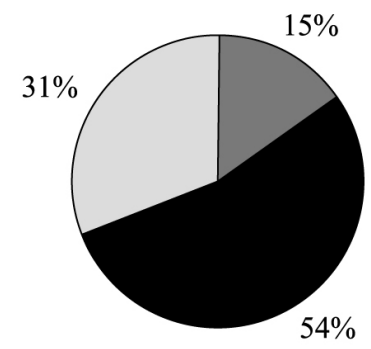

Cyanophyta Chlorophyta $\square$ Heterokontophyta

Figure 2. Proportion of the number species per division in the water samples from the channel that links the reservoirs of Moxoto to the reservoir of Paulo Afonso.

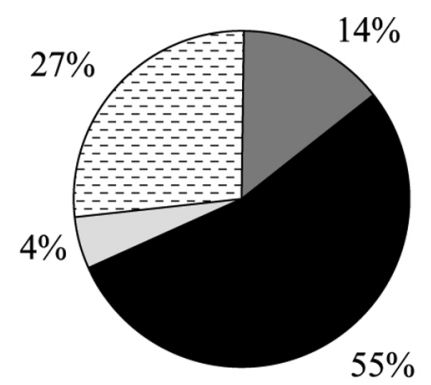

\section{Cyanophyta $\square$ Chlorophyta $\square$ Dinophyta Heterokontophyta}

Figure 3. Proportion of the number species per division within the gastrointestinal tract of $D$. enno $(n=10)$ collected from the channel that links the reservoirs of Moxoto to the reservoir of Paulo Afonso.
Still regarding to the water samples, Coelastrum sp. was present in $100 \%$ of the samples followed by Chroococcus sp. with 75\%. Scenedesmus sp., Staurastrum sp., Aulacoseira sp. 1, Aulacoseira sp. 2, Monoraphydium sp., Merismopedia sp. and Golenkinia sp. were present in $50 \%$ of the samples. The species Navicula sp., Surirella sp. Closterium sp. and Chlorella sp. were identified in only $25 \%$ of the samples (as shown in Table 2).

Regarding the gastrointestinal phytoplankton contents, $68 \%$ of the Heterokontophyta species were classified as very frequent (VF), 16\% as frequent (F) and the remaining $16 \%$ as infrequent (IF). Relatively to Chlorophyta, 33\% of the identified species were classified as very frequent (VF), $8 \%$ as frequent (F) and 59\% of Chlorophyta as infrequent (IF)(Table 2). Concerning the Cyanophyta division, $67 \%$ of the identified species were classified as frequent (F) and 33\% as infrequent (IF) (as shown in Table 2). The only Dinophyta species was classified as infrequent (IF) (Table 2).

The frequency index in relation to the genus and species observed in the gastrointestinal content showed an occurrence of the Staurastrum sp.a and the Aulacoseira sp. 2 in $100 \%$ of the samples (as shown in Table 2). Among the other identified species, the following were observed in a large amount of gut/stomach samples: Aulacoseira sp. 1 (90\%), Fragilaria crotonensis (90\%), Scenedesmus sp. (90\%), Surirella sp. (80\%), Pediastrum clathratum (70\%), Coelastrum sp. (70\%) and Navicula sp. $(60 \%)$. The remaining species occurred in $50 \%$ or less of the samples (as shown in Table 2).

\section{Discussion}

\subsection{Physical and chemical water parameters}

The distribution of benthic organisms in lotic ecosystems is directly related to the water current, quality and availability of food, type of substratum (sandy, stone, wood, aquatic macrophytes), water temperature, and the concentrations of dissolved oxygen, alkalinity, $\mathrm{pH}$ and ammonium (Palmer et al., 1994; Quinn et al. 1994; Townsend et al. 1997).

According to Callisto et al. (2005), the stretch between Moxotó and Paulo Afonso, where the present study was conducted, is in process of artificial eutrophication and has a high biomass of aquatic macrophytes. Callisto et al. (2005) reported as well substrate diversification and an increase in biodiversity and richness of freshwater bivalves. Furthermore, the development of a community dominated by molluscs in both dry and rainy periods was recorded, associated with particular physical and chemical characteristics, as higher $\mathrm{pH}$, high values of total alkalinity and aquatic macrophytes (Callisto et al., 2005).

In the present study the physical parameters registered in Paulo Afonso revealed that the temperature was normal for that time of the year (April, rainy season) and that waters were also relatively well oxygenated. The $\mathrm{pH}$ values were above 7 and therefore appropriate for the development of mollusc communities. The alkalinity values found now 
Table 2. Spectrum and frequency of occurrence of phytoplankton taxa identified in water samples and gastrointestinal tracts of 10 D. enno samples from São Francisco river and its classification according to the CETESB (1978) criteria.

\begin{tabular}{|c|c|c|c|c|c|c|c|c|c|c|c|c|c|c|c|c|}
\hline & \multicolumn{5}{|c|}{$\begin{array}{l}\text { Microalgae present in } \\
\text { water }\end{array}$} & \multicolumn{11}{|c|}{ Microalgae from the gastrointestinal tract of $D$. enno } \\
\hline & $\bar{z}$ & 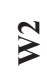 & 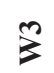 & $\vec{z}$ & $x^{\circ}$ & כ0 & ปี & Z & ت & 8 & ن & ڤ & ڤ̊ & 今 & $\stackrel{0}{0}$ & $x^{\circ}$ \\
\hline \multicolumn{17}{|l|}{ Cyanophyta } \\
\hline Chroococcus sp. & $\mathrm{x}$ & - & $\mathrm{x}$ & $\mathrm{x}$ & $\mathrm{VF}$ & - & - & $\mathrm{x}$ & $\mathrm{x}$ & $\mathrm{x}$ & $\mathrm{x}$ & - & - & $\mathrm{x}$ & - & $\mathrm{F}$ \\
\hline Merismopedia sp. & - & - & $\mathrm{x}$ & $\mathrm{x}$ & $\mathrm{F}$ & - & $\mathrm{x}$ & - & - & $\mathrm{x}$ & $\mathrm{x}$ & - & - & $\mathrm{x}$ & - & IF \\
\hline Chroococcus minutus & - & - & - & - & A & - & $\mathrm{x}$ & - & $\mathrm{x}$ & $\mathrm{x}$ & $\mathrm{x}$ & $\mathrm{x}$ & - & - & - & $\mathrm{F}$ \\
\hline \multicolumn{17}{|l|}{ Chlorophyta } \\
\hline Chlorella sp. & - & - & - & $\mathrm{x}$ & $\mathrm{IF}$ & $\mathrm{x}$ & - & $\mathrm{x}$ & - & - & - & - & - & - & $\mathrm{x}$ & IF \\
\hline Coelastrum sp. & $\mathrm{x}$ & $\mathrm{x}$ & $\mathrm{x}$ & $\mathrm{x}$ & VF & $\mathrm{x}$ & $\mathrm{x}$ & - & $\mathrm{x}$ & - & $\mathrm{x}$ & $\mathrm{x}$ & - & $\mathrm{x}$ & $\mathrm{x}$ & VF \\
\hline Scenedesmus sp. & $\mathrm{x}$ & - & - & $\mathrm{x}$ & $\mathrm{F}$ & - & $\mathrm{x}$ & $\mathrm{x}$ & $\mathrm{x}$ & $\mathrm{x}$ & $\mathrm{x}$ & $\mathrm{x}$ & $\mathrm{x}$ & $\mathrm{x}$ & $\mathrm{x}$ & VF \\
\hline Pandorina sp. & - & - & - & - & $\mathrm{A}$ & - & $\mathrm{x}$ & - & - & - & - & - & - & - & $\mathrm{x}$ & IF \\
\hline Pediastrum duplex & - & - & - & - & $\mathrm{A}$ & $\mathrm{x}$ & - & $\mathrm{x}$ & $\mathrm{x}$ & - & - & $\mathrm{x}$ & - & - & - & IF \\
\hline Pediastrum simplex & - & - & - & - & A & - & - & - & - & - & - & - & - & $\mathrm{x}$ & & IF \\
\hline Pediastrum clathratum & - & - & - & - & $\mathrm{A}$ & $\mathrm{x}$ & - & $\mathrm{x}$ & $\mathrm{x}$ & $\mathrm{x}$ & $\mathrm{x}$ & $\mathrm{x}$ & - & - & $\mathrm{x}$ & $\mathrm{VF}$ \\
\hline Monoraphidium sp. & - & $\mathrm{x}$ & - & $\mathrm{x}$ & $\mathrm{F}$ & - & $\mathrm{x}$ & - & $\mathrm{x}$ & - & - & - & - & $\mathrm{x}$ & - & IF \\
\hline Golenkinia sp. & $\mathrm{x}$ & $\mathrm{x}$ & - & - & $\mathrm{F}$ & - & - & - & - & - & - & - & - & - & - & $\mathrm{A}$ \\
\hline Cosmarium sp. & - & - & - & - & A & - & - & - & $\mathrm{x}$ & - & - & - & - & - & - & IF \\
\hline $\begin{array}{l}\text { Staurastrum } \\
\text { cf. leptocladium }\end{array}$ & - & - & - & - & A & $\mathrm{x}$ & - & - & $\mathrm{x}$ & $\mathrm{x}$ & - & $\mathrm{x}$ & - & - & $\mathrm{x}$ & $\mathrm{F}$ \\
\hline Staurastrum sp. & - & $\mathrm{x}$ & - & $\mathrm{x}$ & $\mathrm{F}$ & $\mathrm{x}$ & $\mathrm{x}$ & $\mathrm{x}$ & $\mathrm{x}$ & $\mathrm{x}$ & $\mathrm{x}$ & $\mathrm{x}$ & $\mathrm{x}$ & $\mathrm{x}$ & $\mathrm{x}$ & VF \\
\hline Closterium sp. & - & - & $\mathrm{x}$ & - & IF & - & - & - & & $\mathrm{x}$ & - & $\mathrm{x}$ & - & - & - & IF \\
\hline Dinophyta & & & & & & & & & & & & & & & & \\
\hline $\begin{array}{l}\text { Gymnodinium sp. } \\
\text { Heterokontophyta }\end{array}$ & - & - & - & - & A & - & - & - & - & - & $\mathrm{x}$ & $\mathrm{x}$ & - & - & - & IF \\
\hline Aulacoseira sp. 1 & - & $\mathrm{x}$ & $\mathrm{x}$ & - & $\mathrm{F}$ & $\mathrm{x}$ & $\mathrm{x}$ & $\mathrm{x}$ & $\mathrm{x}$ & $\mathrm{x}$ & $\mathrm{x}$ & $\mathrm{x}$ & $\mathrm{x}$ & - & $\mathrm{x}$ & $\mathrm{VF}$ \\
\hline Aulacoseira sp. 2 & - & $\mathrm{x}$ & - & $\mathrm{x}$ & $\mathrm{F}$ & $\mathrm{x}$ & $\mathrm{x}$ & $\mathrm{x}$ & $\mathrm{x}$ & $\mathrm{x}$ & $\mathrm{x}$ & $\mathrm{x}$ & $\mathrm{x}$ & $\mathrm{x}$ & $\mathrm{x}$ & VF \\
\hline Cymbella sp. & - & - & - & - & A & - & - & $\mathrm{x}$ & $\mathrm{x}$ & - & - & - & - & - & - & IF \\
\hline Fragilaria crotonensis & - & - & - & - & $\mathrm{A}$ & - & $\mathrm{x}$ & $\mathrm{x}$ & $\mathrm{x}$ & $\mathrm{x}$ & $\mathrm{x}$ & $\mathrm{x}$ & $\mathrm{x}$ & $\mathrm{x}$ & $\mathrm{x}$ & VF \\
\hline Surirella sp. & $\mathrm{x}$ & - & - & - & IF & - & $\mathrm{x}$ & $\mathrm{x}$ & $\mathrm{x}$ & $\mathrm{x}$ & $\mathrm{x}$ & $\mathrm{x}$ & $\mathrm{x}$ & - & $\mathrm{x}$ & VF \\
\hline Navicula sp. & - & $\mathrm{x}$ & - & - & $\mathrm{IF}$ & - & $\mathrm{x}$ & $\mathrm{x}$ & $\mathrm{x}$ & $\mathrm{x}$ & - & $\mathrm{x}$ & - & - & $\mathrm{x}$ & $\mathrm{F}$ \\
\hline
\end{tabular}

in the Paulo Afonso region were higher than the values observed by Ishii (1987) and Sampaio and López (2003) in the São Francisco river, downstream of Três Marias dam, and were also higher than the values reported by Callisto et al. (2005) in the São Francisco river, measured in 1997 next to Paulo Afonso reservoir. Therefore, the physical parameters of the water: temperature, $\mathrm{pH}$ and alkalinity may favour the growth and the maintenance of D. enno mollusc.

\subsection{Phytoplankton composition}

Precise knowledge of the natural diets of bivalve populations, particularly the phytoplankton composition, is of prime importance for the understanding of growth and dynamics of these populations (Beukema and Cadee, 1991). However, results are very often difficult to interpret because of the various factors of selection of microalgae interacting across the feeding processes of bivalves (Navarro and Iglesias, 1993; Rouillon and Navarro, 2003).
The identification and comparison of stomach content and seston phytoplankton compositions in terms of frequency and abundance of species constitutes a useful approach to this subject. Microalgae have been considered as the main food source for captive mollusc bivalves, since they are filter feeders from early juvenile stage (Kovitvadhi et al. 2006).

The importance of algal species as a food source for captive juvenile mussels is likely a balance between their physical characteristics and nutritional properties (Mummert, 2001). Adult unionids have displayed an ability to sort algae prior to ingestion based on cellular characteristics, such as size, shape, chemical constituents, structure components and specific aggregation properties (Paterson, 1984, 1986; Miura and Yamashiro, 1990; Gatenby et al., 1996; Baker et al., 2000; Baker and Levinton, 2003).

Taking into account the dimension of the particles present in the gastrointestinal contents, the frequency index of Scenedemus sp. (90\%), Coelastrum sp. (70\%) and Chroococcus sp. (50\%), can indicate a facilitated filtration 
rate for small size species (7-15 $\mu \mathrm{m})$. According to Morton (1971) and Sprung (1984), small algae cells can be filtered at higher rates, whereas larger ones are filtered at lower rates. Furthermore, the small phytoplankton was predominant in the distribution both in water and gastrointestinal tract, as it is observed for Chlorophyta division (at 54\% in both water and tract). This is in accordance with Parker et al. (1998), that pointed out the relative abundance of algal species within the gut contents of adult Amblema plicata and Quadrula pustulosa from the Ohio River was similar to their relative abundance in the external environment.

Nevertheless, other small microalgae absent in the water were found in the gastrointestinal tract in reasonable percentage, such as Chroococcus minutus (50\%) and Pediastrum clathratum (70\%). This strange observation may be explained by a very fast dynamic fluctuation of these microalgae in the river, associated with a longer digestion time. Another remote possibility is the slow development of the microalgae, which would be accomplished during the digestive process, and so microalgae were living outside (in the water) under an undifferentiated form. Eventually, this same explanation could be applied for the large phytoplankton spectra in the stomach/gut comparatively to the water where some others are absent.

On the other hand, the size and frequency cannot totally explain the considerable presence within the stomach/gut contents of some oversized microalgae $(22-43 \mu \mathrm{m})$. In fact, Navicula sp. and Surirella sp., both at $25 \%$ in the water samples, presented an expressive value of $60 \%$ and $80 \%$ in the gastrointestinal content, respectively. Moreover, other oversized microalgae, such as Staurastrum sp., Aulacoseira sp. 1 and Aulacoseira sp.2, although showing a moderate occurrence frequency in the water samples $(50 \%)$, exhibited a maximum percentage of $100 \%$ in the tract of $D$. enno bivalve. Thus, it is possible to admit that the high prevalence of large size microalgae, observed inside bivalve tract, can be mainly due to the chemical/physical properties of these microalgae, which may represent a nutritional advantage to these bivalves.

\subsection{Algal diet perspectives}

Gatenby et al. (1997) studied the growth and survival of $V$. iris juveniles testing several different microalgae diets. Juveniles didn't grow as well when fed with chlorophytes, that was justified by the lack of a substantial amount of polyunsaturated fatty acids (PUFA) and by their low nutritional value (Pohl and Zurheide, 1979; Paterson, 1984; Ahlgren et al., 1992; Beck, 2001; Beck and Neves, 2003). On the other hand, the diet composed by diatoms showed better growth results since they are characterized by possessing a high percentage of unsaturated and polyunsaturated fatty acids (UFA and PUFA and oil reserves (lipids) (Erwin, 1973; Werner, 1978; Pohl and Zurheide, 1979; Ahlgren et al. 1992). Based on the results obtained by Gatenby et al. (1997) and analysing of the percentage of species classified with high frequency index observed in the present study, one can conclude that the outstanding presence of diatoms in the gastrointestinal contents is due to their high content in PUFA and UFA, and the high number of taxa of the Chlorophyta division is explained exclusively by the fact that a larger number of taxa were found in the water samples as well.

In summary, algal species have been incorporated, in several works, into the design of direct or recirculating systems of juvenile cultures as the primary food source, due to their apparent significance in the diet of unionoids (Hudson and Isom, 1984; Gatenby et al., 1996, 1997; O'Beirn et al., 1998; Tankersley and Butz, 2000; Henley et al., 2001; Kovitvadhi et al., 2008).

Moreover, Lima et al. (2002) studied the growth of A. cygnea's young adults mentioning a strong increase in the weight of the animals during autumn, which was related to the high percentage of diatoms during that season. Similar results were presented by Beukema \& Cadee (1991) and Gatenby et al. (1997). Based on the analysis of the present findings, we suggest a mixture of smaller chlorophytes and large diatoms as an appropriate diet to rear the mussel $D$. enno. Nevertheless, these statements regarding the influence of size and frequency of microalgae should be deeply studied in laboratory works, in order to offer better nutritional conditions for the survival and maintenance of D. enno.

\section{Acknowledgements}

We would like to thank to Dr. José Carlos Nascimento de Barros, to Dr. Tâmara Almeida, Dr. Maria Cristina Mansur and Dr. Igor Christo Miyahira for all the suggestions and advice. This work was partially supported by the Portuguese Foundation for Science and Technology (FCT) under the projects PTDC/AAC-AMB/117688/2010 and CIIMARPlurianual Program.

\section{References}

AHLGREN, G., GUSTAFSSON, I. and BOBERG, M., 1992. Fatty acid and chemical composition of freshwater microalgae. Journal of Phycology, vol. 28, no. 1, pp. 37-50. http://dx.doi. org/10.1111/j.0022-3646.1992.00037.x.

ALDRIDGE, D.W., PAYNE, B.S. and MILLER, A.C., 1987. The effects of intermittent exposure to suspended solids and turbulence on three species of freshwater mussels. Environmental Pollution, vol. 45, no. 1, pp. 17-28. http://dx.doi.org/10.1016/02697491(87)90013-3. PMid:15092759.

AVELAR, W.E.P., NEVES, F.F. and LAVRADOR, M.A.S., 2014. Modelling the risk of mortality of Corbicula fluminea (Müller, 1774) (Bivalvia: Corbiculidae) exposed to different turbidity conditions. Brazilian Journal of Biology = Revista Brasileira de Biologia, vol. 74, no. 2, pp. 509-514. http://dx.doi. org/10.1590/1519-6984.21612. PMid:25166339.

BAKER, M. and LEVINTON, S., 2003. Selective feeding by three native North American freshwater mussels implies food competition with zebra mussels. Hydrobiologia, vol. 505, no. 1-3, pp. 97-105. http://dx.doi.org/10.1023/B:HYDR.0000007298.52250.99.

BAKER, S., LEVINTON, J. and WARD, J., 2000. Particle transport in the zebra mussel, Dreissena polymorpha (Pallas). The 
Biological Bulletin, vol. 199, no. 2, pp. 116-125. http://dx.doi. org/10.2307/1542871. PMid:11081710.

BECK, K. and NEVES, R.J., 2003. An evaluation of selective feeding by three age groups of the rainbow mussel (Villosa iris). North American Journal of Aquaculture, vol. 65, no. 3, pp. 203209. http://dx.doi.org/10.1577/C02-031.

BECK, K., 2001. Development of an algal diet for rearing juvenile freshwater mussels (Unionidae). Blacksburg: Virginia Polytechnic Institute and State University, 58 p. Master Dissertation.

BEUKEMA, J. and CADEE, G., 1991. Growth rates of the bivalve Macoma balthica in the Wadden Sea during a period of eutrophication: relationships with concentrations of pelagic diatoms and flagellates. Marine Ecology Progress Series, vol. 68, pp. 249-256. http://dx.doi.org/10.3354/meps068249.

BOGAN, A. E., 2008. Global diversity of freshwater mussels (Mollusca, Bivalvia) in freshwater. Hydrobiologia, vol. 595, pp. 139-147.

BOGAN, A.E., 1993. Freshwater bivalve extinctions (Mollusca: Unionoida): a search for causes. American Zoologist, vol. 33, no. 6, pp. 599-609. http://dx.doi.org/10.1093/icb/33.6.599.

BOURRELLY, P., 1966. Les algues d'eau douce. Paris: Éditions N. Boubée \& Cie. 572 p. Tome I: Les algues vertes.

BOURRELLY, P., 1968. Les algues d'eau douce. Paris: Éditions N. Boubée \& Cie. 440 p. Tome II: Les algues jaunes et brunes.

BRANCO, S.M., 1978. Hidrobiologia aplicada à engenharia sanitária. 2nd ed. São Paulo: Companhia de Tecnologia de Saneamento Ambiental. 620 p.

CALLISTO, M., GOULART, M., BARBOSA, F.A.R. and ROCHA, O., 2005. Biodiversity assessment of benthic macroinvertebrates along a reservoir cascade in the lower São Francisco river (northeastern Brazil). Brazilian Journal of Biology $=$ Revista Brasileira de Biologia, vol. 65, no. 2, pp. 229-240. http://dx.doi. org/10.1590/S1519-69842005000200006. PMid:16097725.

COMPANHIA DE TECNOLOGIA DE SANEAMENTO AMBIENTAL - CETESB, 1978. Determinação do zooplâncton marinho: métodos qualitativos e quantitativos. São Paulo: CETESB. 13 p. Normalização técnica L5-301.

DUDGEON, D. and MORTON, B., 1984. Site selection and attachment duration of Anodonta woodiana (Lea, 1934) (Bivalvia: Unionacea) glochidia on fish hosts. Journal of Zoology, vol. 204, no. 3, pp. 355-362. http://dx.doi.org/10.1111/j.1469-7998.1984. tb02378.x.

ELDER, J.F. and COLLINS, J.J., 1991. Freshwater molluscs as indicators of bioavailability and toxicity of metals in surfacewater systems. Reviews of Environmental Contamination and Toxicology, vol. 122, pp. 37-79. PMID: 1771274.

ERWIN, J.A., 1973. Comparative biochemistry of fatty acids in eukaryotic microorganisms: lipids and biomembranes of eukaryotic organisms. New York: Academic Press. 354 p.

GATENBY, C.M., NEVES, R.J. and PARKER, B.C., 1996. Influence of sediment and algal food on cultured juvenile freshwater mussels. Journal of the North American Benthological Society, vol. 15 , no. 4 , pp. 597-609. http://dx.doi.org/10.2307/1467810.

GATENBY, C.M., PARKER, B.C. and NEVES, R.J., 1997. Growth and survival of juvenile rainbow mussels, Villosa iris (Lea, 1929) (Bivalvia: Unionidae), reared on algal diets and sediment. American Malacological Bulletin, vol. 14, no. 1, pp. 57-66.

GAZULHA, V., MANSUR, M. C. D., CYBIS, L. F. and AZEVEDO, S. M. F. O., 2012. Feeding behavior of the invasive bivalve Limnoperna fortunei (Dunker, 1857) under exposure to toxic cyanobacteria Microcystis aeruginosa. Brazilian Journal of Biology, vol. 72, no. 1, pp. 41-49. PMid:22437383.

HELLER, J., 1990. Longevity in molluscs. Malacologia, vol. 31 , no. 2, pp. 259-295.

HENLEY, W.F., ZIMMERMAN, L.L., NEVES, R.J. and KIDD, M.R., 2001. Design and evaluation of recirculating water systems for maintenance and propagation of freshwater mussels. North American Journal of Aquaculture, vol. 63, no. 2, pp. 144-155. http://dx.doi.org/10.1577/1548-8454(2001)063<0144:DAEOR $\mathrm{W}>2.0 . \mathrm{CO} ; 2$.

HUDSON, R.G. and ISOM, B.G., 1984. Rearing juveniles of the freshwater mussels (Unionidae) in a laboratory setting. The Nautilus, vol. 98, pp. 129-135.

ISHII, I.H., 1987. Contribuição ao estudo do ciclo do carbono na represa de Três Marias, MG. São Carlos: Universidade Federal de São Carlos, 159 p. Masters Dissertation.

KOTPAL, R.L., 1997. Mollusca. New Deli: Rastogi Publications. $240 \mathrm{p}$.

KOVITVADHI, S., KOVITVADHI, U., SAWANGWONG, P. and MACHADO, J., 2008. A laboratory-scale recirculating aquaculture system for juveniles of freshwater pearl mussel Hyriopsis (Limnoscapha) myersiana (Lea, 1856). Aquaculture, vol. 275, no. 1-4, pp. 169-177. http://dx.doi.org/10.1016/j. aquaculture.2007.12.029.

KOVITVADHI, S., KOVITVADHI, U., SAWANGWONG, P., THONGPAN, A. and MACHADO, J., 2006. Optimization of diet and culture environment for larvae and juvenile freshwater pearl mussels, Hyriopsis (Limnoscapha) myersiana. Invertebrate Reproduction \& Development, vol. 49, no. 1-2, pp. 61-70. http:// dx.doi.org/10.1080/07924259.2006.9652194.

KOVITVADHI, U., PAKKONG, P., NOPARATNARAPORN, N., VILARINHO, L. and MACHADO, J., 2002. Study of suitable fish plasma for in vitro culture of glochidia Hyriopsis myersiana. Aquaculture, vol. 209, no. 1-4, pp. 197-208. http:// dx.doi.org/10.1016/S0044-8486(01)00870-5.

LEE, R.E., 1999. Phycology. Cambridge: Cambridge University Press. $614 \mathrm{p}$

LIMA, P., CARVALHO, F., VASCONCELOS, V. and MACHADO, J., 2002. Studies on growth in the early adult of the freshwater mussel Anodonta cygnea. Invertebrate Reproduction \& Development, vol. 45 , no. 2 , pp. 117-125. http://dx.doi.org/10.1080/0792425 9.2004.9652581.

LIMA, R.C.L., 2010. Proportion of the number species per division in the water samples from the channel that links the reservoirs of Moxoto to the reservoir of Paulo Afonso. Faculdade de Filosofia, Ciências e Letras de Ribeirão Preto, Universidade de São Paulo, 138 p. Doctoral Thesis.

LYDEARD, C., COWIE, R.H., PONDER, W.F., BOGAN, A.E., BOUCHET, P., CLARK, S.A., CUMMINGS, K.S., FREST, T.J., GARGOMINY, O., HERBERT, D.G., HERSHLER, R., PEREZ, K., ROTH, B., SEDDON, M., STRONG, E. and THOMPSON, F.G., 2004. The global decline of nonmarine mollusks. Bioscience, vol. 54, no. 4, pp. 321-330. http://dx.doi.org/10.1641/00063568(2004)054[0321:TGDONM]2.0.CO;2.

MACHADO, A.B.M., MARTINS, C.S. and DRUMMOND, G.M., 2005. Lista da fauna brasileira ameaçada de extinção: incluindo as espécie quase ameaçadas e deficientes em dados. Belo Horizonte: Fundação Biodiversitas. 160 p. 
MIURA, T. and YAMASHIRO, T., 1990. Size selective feeding of Anodonta calipygos, a phytoplanktivorous freshwater bivalve, and viability of egested algae. Japanese Journal of Limnology, vol. 51, no. 2, pp. 73-78. http://dx.doi.org/10.3739/rikusui.51.73.

MORTON, B.S., 1971. Studies on the biology of Dreissena polymorpha Pall. V. Some aspects of filter-feeding and the effect of micro-organisms upon the rate filtration. Proceedings of the Malacological Society of London, vol. 39(A), pp. 289-301.

MUMMERT, A.K., 2001. Evaluating the feasibility of rearing juvenile freshwater mussels in a flow-through pond system at white sulphur springs national fish hatchery. Blacksburg: Virginia Polytechnic Institute and State University, 153 p. Masters Dissertation.

NAVARRO, E. and IGLESIAS, J.I.P., 1993. Infaunal filter-feeding bivalves and the physiological response to short-term fluctuations in food availability and composition. In: R.F. DAME, ed. Estuarine and coastal ecosystem processes. Heidelberg: Springer-Verlag, vol. 33, pp. 25-56.

O'BEIRN, F.X., NEVES, R.J. and STEG, M.B., 1998. Survival and growth of juvenile freshwater mussels (Unionidae) in a recirculating aquaculture system. American Malacological Bulletin, vol. 14, no. 2, pp. 165-171.

PALMER, C., PALMER, A., O'KEEFE, J. and PALMER, R., 1994. Macroinvertebrate community structure and altitudinal changes in the upper reaches of a warm temperature southern african river. Freshwater Biology, vol. 32, no. 2, pp. 337-348. http://dx.doi.org/10.1111/j.1365-2427.1994.tb01130.x.

PANHA, S., 1992. Infection experiment of glochidium of a freshwater pearl mussel, Hyriopsis (Limnoscapha) myersiana (Lea, 1856). Venus (Fukuyama-Shi, Japan), vol. 51, no. 4, pp. 303-314.

PARKER, B.C., PATTERSON, M.A. and NEVES, R.J., 1998. Feeding interactions between native freshwater mussels (Bivalvia: Unionidae) and zebra mussels (Dreissena polymorpha) in the Ohio River. American Malacological Bulletin, vol. 14, no. 2, pp. 173-179.

PATERSON, C.G., 1984. A technique for determining apparent selective filtration in the freshwater bivalve Elliptio complanata (Lightfoot). The Veliger, vol. 27, no. 2, pp. 665-672.

PATERSON, C.G., 1986. Particle-size selectivity. I. The freshwater bivalve Elliptio complanata (Lightfoot). The Veliger, vol. 29, no. 2, pp. 235-237.

PEREIRA, D., MANSUR, M C.D. and PIMPÃO, D.M., 2012. Identificação e diferenciação dos bivalves límnicos invasores dos demais bivalves nativos do Brasil. In: M.C.D. MANSUR, D. PEREIRA and C.P. SANTOS. Moluscos límnicos invasores no Brasil: biologia, prevenção e controle. Porto Alegre: Editora Redes, pp. 75-94, 412. Cap. 5.

POHL, P. and ZURHEIDE, F., 1979. Fatty acids and lipids of marine algae and the control of their biosynthesis by environmental factors. In: H.A. HOPPET, Y. LEVRING and T.W. GRUYTER. Marine algae in pharmaceutical science. New York: Walter de Gruyter. 807 p.

QUINN, J.M., STEELE, G.L., HICKEY, C.W. and VICKERS, M.L., 1994. Upper thermal tolerances of twelve New Zealand stream invertebrate species. New Zealand Journal of Marine and Freshwater Research, vol. 28, no. 4, pp. 391-397. http://dx.doi. org/10.1080/00288330.1994.9516629.

RAVERA, O., CENCI, R., BEONE, G.M., DANTAS, M. and LODIGIANI, P., 2003. Trace element concentrations in freshwater mussels and macrophytes as related to those in their environment.
Journal of Limnology, vol. 62, no. 1, pp. 61-70. http://dx.doi. org/10.4081/jlimnol.2003.61.

RODRIGUES, V.G.S., FUJIKAWA, A., ABESSA, D.M.S., HORTELLANI, M.A., SARKIS, J.S. and SÍGOLO, J.B., 2012. Using the freshwater bivalve Anodontites tenebricosus (LEA, 1834 ) as a biomonitor of metals in the Ribeira de Iguape River. Quimica Nova, vol. 35, no. 3, pp. 454-459. http://dx.doi.org/10.1590/ S0100-40422012000300003.

ROUILLON, G. and NAVARRO, E., 2003. Differential utilization of species of phytoplankton by the mussel Mytilus edulis. Acta Oecologica, vol. 24, suppl. 1, pp. 299-305. http://dx.doi.org/10.1016/ S1146-609X(03)00029-8.

SAMPAIO, E.V. and LÓPEZ, C.M., 2003. Limnologias física, química e biológica da represa de Três Marias e do São Francisco. In: H.P. GODINHO and A. L. GODINHO, eds. Águas, peixes e pescadores do São Francisco das Minas Gerais. Belo Horizonte: PUC Minas, pp. 71-92.

SOARES-GOMES, A. and PIRES-VANIN, A.M.S., 2005. Bivalve mollusk assemblages on São Paulo's northern continental shelf, southeast Brazil. Brazilian Journal of Biology = Revista Brasileira de Biologia, vol. 65, no. 4, pp. 717-727. http://dx.doi.org/10.1590/ S1519-69842005000400019. PMid:16532196.

SPRUNG, M., 1984. Physiological energetics of mussel larvae (Mytilus edulis). II. Food uptake. Marine Ecology Progress Series, vol. 17, pp. 283-293. http://dx.doi.org/10.3354/meps017283.

TANKERSLEY, R.A. and BUTZ, S.W., 2000 [viewed 4 April 2014]. Design, construction, and evaluation of a laboratory-scale recirculating aquaculture system for the captive care of freshwater mussels. In: Proceedings of the Conservation, Captive Care, and Propagation of Freshwater Mussels Symposium [online], 1998, Columbus, Ohio. Columbus: Ohio Biological Survey, pp. 127-134. Available from: http://molluskconservation.org/FMCS/ Workshops/1998-9/Symp1998-1999Proc.html

TOWNSEND, C.R., ABRUCKLE, C.J., CROWL, T.A. and SCARSBROOK, M.R., 1997. The relationship between land use and physicochemistry, food resources and macroinvertebrate communities in tributaries of the Taieri River, New Zealand: a hierarchically scaled approach. Freshwater Biology, vol. 37, no. 1, pp. 177-191. http://dx.doi.org/10.1046/j.1365-2427.1997.00151.x.

UTHAIWAN, K., NOPARATNARAPOM, N. and MACHADO, J., 2001. Culture of glochidia of the freshwater pearl mussel Hyriopsis muersiana (Lea, 1856) in artificial media. Aquaculture, vol. 195, no. 1-2, pp. 61-69. http://dx.doi.org/10.1016/S00448486(00)00541-X.

UTHAIWAN, K., PAKKONG, P., NOPARATNARAPORN, N., VILARINHO, L. and MACHADO, J., 2002. Studies of a suitable fish plasma for in vitro culture of glochidia Hyriopsis myersiana (Lea, 1856). Aquaculture, vol. 209, pp. 197-208. http://dx.doi. org/10.1016/S0044-8486(01)00870-5.

VAUGHN, C.C., 2010. Biodiversity losses and ecosystem function in freshwaters: emerging conclusions and research directions. Bioscience, vol. 60, no. 1, pp. 25-35. http://dx.doi.org/10.1525/ bio.2010.60.1.7.

VAUGHN, C.C., NICHOLS, S.J. and SPOONER, D.E., 2008. Community and foodweb ecology of freshwater mussels. Journal of the North American Benthological Society, vol. 27, no. 2, pp. 409-423. http://dx.doi.org/10.1899/07-058.1.

WERNER, D., 1978. Regulation of metabolism by silicate in diatoms. In: G. BENDZ and L. LINDQUIST, eds. Biochemistry of silicon and related problems. New York: Plenum Press. 591 p. 